застосування результатів дослідження уможливлюється створенням і просуванням нових туристичних програм, розробкою лекційних курсів з етнології, лінгвокультурології та туризму.

Ключові слова: туризм, етнокультурна спадщина, лінгвокультурна спадщина, історико-етнографічний регіон.

Valeria A. KAZAKOVA,

Master of Cultural Heritage and Tourism, Head of the Marketing Communications Department of the Center for Corporate Communications of Belarusian State University; 9 Kalvariyskaya str., Minsk, 220004, Republic of Belarus; tel.: +375 (29) 6120391; e-mail: lerakazakova@bk.ru; ORCID ID: 0000-0002-4705-8467

\title{
REPRESENTATION OF ETHNOCULTURAL HERITAGE OF BELARUS IN THE SPHERE OF TOURISM : REGIONAL CONTEXT
}

Summary. The purpose of this article is to consider the importance of the regional ethnic and linguocultural specificity of the Republic of Belarus in matters of representing the ethnocultural heritage in the tourism sector. The object of analysis is the ethnocultural and linguocultural heritage of the Republic of Belarus. The subject of analysis is the regional context of the representation of ethnocultural and linguocultural heritage of the Republic of Belarus in the tourism sector. The method of system analysis and the descriptive method are used in this research. As a result of the study, the regional context of the representation of the ethnocultural and linguocultural heritage of the Republic of Belarus in the tourism sector was considered, the problem field of the issue was identified, the prospects for solutions were outlined.

Findings. Today, the ethnocultural and linguocultural heritage of Belarus is widely represented in the tourism sector in a regional context. However, the ethnocultural authenticity of six Belarusian historical and ethnographic regions is not fully reflected in the existing tourism product and requires additional forms of promotion and representation. Practical application of the research results is possible in the creation and promotion of new tourism programs, the development of lecture courses on the topic of ethnology, linguoculturology and tourism.

Key words: tourism, ethnocultural heritage, linguocultural heritage, historical and ethnographic region.

Статтю отримано 22.10.2019 p.

http://dx.doi.org/10.18524/2307-4558.2019.32.187749

УДК 811.133.1'371'42:161.26

МАРІНАІІВІЛІ Мальвіна Джангізівна,

кандидат філологічних наук, доцент, завідувач кафедри французької філології Одеського національного університету імені I. I. Мечникова; Французький бульвар, 24/26, м. Одеса, 65058, Україна; тел.: +38 098 4406757;

e-mail: malvimari@gmail.com; ORCID ID: 0000-0002-3041-7064

\section{МОВНІ ЗАСОБИ ТВОРЕННЯ ІРОНІЧНОЇ МОДАЛЬНОСТІ У КНИЗІ ОЛІВ’Є МАНЬЇ "DESSINE-MOI UN PARISIEN"}

Анотація. Мета статті полягає у виокремленні й аналізі мовностилістичних засобів актуалізації іронічної модальності в книзі Олів’ Маньї “Dessine-moi un Parisien» (“Намалюй мені парижанина»), яка належить до жанру нонфікшн. Об'єктом дослідження є вербально виражена іронічна модальність. Предметом вивчення є мовні засоби, які сприяють творенню іронічних смислів в книзі О. Маньї. Результатом проведеного дослідження стало виявлення й опис засобів реалізації авторської іронічної модальності у процесі творення автором образу сучасного парижанина як на рівні мікроконтексту, так і на рівні цілого тексту. Описано лексико-стилістичні та логіко-смислові засоби творення іронічної модальності (епітети, лексичні оказіоналізми, метафора, гіпербола, оксюморон), а також засоби актуалізації асоціативної іронії (лексичний повтор, алюзія). Зроблено висновок про те, що основною функцією, яку іронія виконує у вищезазначеному творі О. Маньї, є функція іронічної (авто)портретизації, вираження авторської оцінки. Іронія в дослідженому творі заснована на викритті суперечного характеру парижанина, невідповідності між зовнішніми виявами та істинною внутрішньою сутністю, якою їі бачить автор, сам докорінний парижанин. Ефективними актуалізаторами іронічного смислу у книзі О. Маньї є також синтактико-стилістичні засоби, дослідження яких видається перспективним у подальших розвідках.

Ключові слова: іронічна модальність, мовностилістичні засоби, французька мова, нон-фікшн, Олів’є Маньї.

Постановка проблеми. Постмодерн як історичний етап у розвитку світової культури породив не лише нові культурні феномени та соціальні процеси, але й новий тип колективного сприйняття, світовідчуття та світобачення, який характеризується як (іронічний) [5, с. 120]. Іронія 6 атрибутом і сутнісною характеристикою постмодерністської культури, в тому числі і літератури, як художньої, так і документальної. “Характерною рисою постмодерної літератури є іронічне ставлення не лише до навколишньої дійсності, а й до самого себе, до самого людського існування, і до мови як способу 
вираження внутрішнього стану письменника» [4, с. 6-7]. 3 огляду на це, дослідження механізмів і засобів творення іронії в текстах жанру нон-фокшн видається актуальним.

Зв'язок із попередніми та суміжними дослідженнями проблеми. Феномен іронії розглядають у наукових працях у різних аспектах, зокрема, естетичному (М. Бахтін, Ю. Борєв, Б. Дземідок, В. Півоєв, В. Пропп та ін.), літературознавчому (Ф. Амон, Л. Болдіна, Д. Мюкке та ін.), лінгвістичному (К. Воробйова, А. Горностаєва, О. Єрмакова, О. Кагановська, О. Калита, К. Кербрат-Орекьні, Ю. Мухіна, Л. Перрен, О. Петрова, С. Походня, А. Приходько, М. Слепцова та ін.). В сучасній лінгвістиці існує два підходи до визначення іронії. 3 одного боку, іронія розглядається як стилістичний прийом, з іншого - як результат, ефект, іронічний смисл. Як свідчать дослідження іронії на рівні тексту, вона може виражатися на всіх рівнях мови, створюючи іронічний ефект, іронічну модальність, іронічну експресію [7; 4]. Зокрема, С. Походня розглядає іронію як форму “оціночного, критичного, емоційного освоєння дійсності) [7, с. 8]. На основі такого підходу іронію можна вважати емоційно-оцінним смислом висловлення [8, с. 284]. Інакше кажучи, іронія в сучасній лінгвістиці має статус концептуальної текстової категорії, яка репрезентує прагматичну настанову автора. Отже, в нашому досліджені ми розглядаємо іронію як форму комізму, яка виражається в емоційно-оцінному естетичному суб' єктивованому ставленні до дійсності, характеризується триплановою структурою вираження при відносній рівноправності цих планів, амбівалентністю, здатністю до двоспрямованості і специфічним емоційним переживанням [4, с. 33].

Формулювання дослідницьких завдань. Мета статті - дослідити мовностилістичні засоби актуалізації іронічної модальності у процесі авторського творення Олів’є Маньї образу парижанина у книзі “Dessine-moi un Parisien». Об'єкт дослідження - вербально виражена іронічна модальність. Предметом вивчення є мовні засоби, які сприяють творенню іронічних смислів у вищезазначеній книзі О. Маньї. Для досягнення мети дослідження використано методи спостереження, аналізу фактичного мовного матеріалу, семантико-стилістичний метод і метод інтерпретаційно-текстового аналізу.

Виклад основного матеріалу. Олів’ Маньї - засновник спілки дегустаторів вина “О Шато». Він має свій блог, у якому, з-поміж іншого, він представив англійською мовою цикл невеликих іронічних нарисів про парижан, описавши їхні характерні риси та звички. Саме ці нариси з блогу, який викликав великий інтерес у читачів, Олів’є Маньї опублікував у 2010 році в паперовому форматі, об’ єднавши їх під назвою (Dessine-moi un Parisien».

Книга Олів'є Маньї належить до жанру нон-фрікшн. Існує низка гумористичних творів цього жанру, присвячених французам i, зокрема, парижанам, серед яких: “A year in ze merde» Стефбана Кларка, "The Xenophobe's Guide to the French» Ніка Яппа і Мішеля Сіретта, "Ces impossibles Français») i “Les Parisiens sont pires que vous ne le croyez» Луї-Бернара Робітайя. Проте, ці книги написані іноземцями, отже, іронія, з якою описано французів, є екстравертною (за термінологією В. Півоєва [6]). Книгу ж (Dessine-moi un Parisien» написав докорінний парижанин. Отже, вона становить особливий інтерес для лінгвістичного аналізу, оскільки є певною мірою (автопортретом», а іронія, що пронизує твір, є іронією амбівалентною.

(Dessine-moi un Parisien» містить 68 невеликих за об’ ємом розділів (2-3 сторінки тексту), в яких автор наводить основні правила життя в Парижі, описує речі, без яких неможливо уявити життя парижанина (острів Сен-Луї та морозиво Бертійон, суші, набір десертів (кафе-гурман», вода (Сан-Пе», солона карамель, TGV тощо). Розділи книги О. Маньї можна розподілити на декілька тематичних категорій: мовленнєві особливості парижан (цей аспект розглянуто у статті [10]), кулінарні пристрасті, улюблені місця, відпочинок, стиль, ставлення до співвітчизників-не-парижан та іноземців, освіта, правила життя у французькій столиці. Наприкінці кожного розділу автор наводить жартівливі корисні поради, як підтримувати розмову на паризький манер та вести себе як справжній парижанин. Наприклад, до розділу “New York» додається:

CONSEIL UTILE:

Ne dites jamais que vous préférez Paris à NY

vous passeriez pour un vieux et un rabat

PARLEZ PARISIEN:

(New York, c'est vraiment super, y a une énergie...) [9, c. 128].

Незважаючи на різноманітність тем, яких торкається автор, всі вони так чи інакше спрямовані на створення “(авто)портрету» парижанина в широкому сенсі цього терміну. Ярко виражена іронічна модальність книги Маньї сприяє її експресивності щодо характеристики головних рис жителів французької столиці.

Основою іронії у творі Маньї є контраст, що викриває, перш за все, протиріччя видимості і суті: того, якими парижани себе вважають, і якими вони є насправді, принаймні, якими їх бачить автор докорінний парижанин. Наведемо декілька прикладів.

Парижани, як і всі французи, обожнюють TGV (швидкісний поїзд). Для них у списку чудових речей, що створені у Франції, TGV посідає перше місце, залишаючи позаду, наприклад, рівність між людьми чи знамените біле вино Château-d'Yquem: „Dans une discussion entre Parisiens sur les choses formidables que la France a eu le bon goût d'enfanter, le TGV vient généralement tout en haut de la liste, bien avant l'égalité entre les hommes ou le Château-d'Yquem» ("Le TGV») [9, с. 25]. Проте, на 
відміну від жителів провінції, парижанин сприймає TGV зовсім не як транспорт швидкого пересування. Для нього найголовніше те, що карта маршрутів TGV є свідченням того, що Франція - це сузір'я, а Париж - його сонце: "Mais, là où le provincial apprécie le TGV car il rend Paris et donc le monde plus accessible, le Parisien bénéficie du TGV dans une tout autre mesure. La carte des lignes TGV nous apprend que la France est une constellation dont Paris est le Soleil) (“Le TGV») [9, c. 25].

Іронічно характеризує О. Маньї ставлення парижан до іноземців. Так, розділ “Les Belges» починається з твердження, що парижани дуже добрі антропологи і здатні охарактеризувати інші народи одним прикметником, як це можуть зробити лише досвідчені експерти: “Les Parisiens sont tous des anthropologues de haut vol. Ils connaissent sur le bout des doigts les autres peuples et les autres pays. Comme seuls les experts savent le faire, ils parviennent à synthétiser leur savoir sur les gens d'ailleurs en un seul adjectif, définitif et inattaquable» [9, c. 160]. Тут автор використовує епітети, що в контексті набувають іронічної конотації de haut vol, définitif, inattaquable. Утім, іронічний ефект цього уривку значно посилюється, коли далі Маньї наводить ті оцінні (експертні) прикметники, які виявляються абсолютно суб'єктивними: "Ainsi, les Américains sont cons, les Portugais poilus, les Vietnamiens chinois et les Belges sympası [9, c. 160].

Ще одна особливість парижан, схарактеризована в окремому розділі “Se plaindre», — їхня звичка постійно скаржитись, яку вони звели в ранг мистецтва: “Si le Français s’est taillé une jolie réputation pour sa façon de continuellement se plaindre, le Parisien élève cette habitude au rang d'art» [9, c. 211]. Парижанин завжди знайде, чим або ким бути незадоволеним: “Avec un indéniable talent, le Parisien réussit à ternir sa réalité en toute situation. Il trouvera toujours quelque chose dont il pourra se plaindre: la qualité d'un plat, les gens, le métro, le boulot, les politiques, les voisins...) [9, с. 200]. Іронічний ефект у наведеному уривку створено використанням словосполучення un indéniable talent ("безперечний талант») по відношенню до ternir sa réalité (у прямому значенні — (робити тьмяним», a в переносному - (бруднити, поганити»), що означають не дуже поєднувані поняття.

Людина, яка постійно скаржиться, за визначенням, є людиною розумною: “L'homme heureux ne peut qu'être idiot. À l'inverse, celui qui se plaint doit nécessairement être intelligent. Un superbe syllogisme parisien est ici à l'œuvre: la personne qui se plaint est celle qui a identifié le problème. La personne qui a identifié le problème est la personne intelligente» ((Se plaindre») [9, c. 211].

Іронія є багатогранним феноменом, що проявляється в її перетині з іншими формами комічного, такими як гумор, жарт, сатира, сарказм та ін. [2]. Іронія може наближатися до того чи іншого суміжного явища, тяжіти до комічного або трагічного, бути жартівливою або сумною. Іронія виражає суб'єктивне ставлення до світу й містить різний підтекст - від апатії до агресивності, від веселого добродушного жарту до в'їдливого глузування [3, с. 105]. У книзі Олів'є Маньї іронія найчастіше добродушно насмішкувата, в деяких контекстах поблажлива.

Парижани впевнені у своїй вищості, причому не лише стосовно всіх, хто не мешкає у столиці, але й щодо інших парижан, що яскраво показано в розділі (Se garer». Парижанин паркує свій автомобіль, як йому заманеться, не думаючи про інших: “Le Parisien se gare n’importe comment. Et s'en réjouit. Se garer n'importe comment est une triple victoire pour le Parisien. Le message envoyé est clair: le Parisien est supérieur aux autres et à la loi. Il se sent déjà bien. Mais le plaisir le plus gourmand de l'affaire est de voir cette supériorité en action. Je suis supérieur et j'agis de façon supérieure. Ce qui me rend sur-supérieur ) $[9$, c. 172].

Створенню іронічного ефекту в книзі Маньї великою мірою сприяє використання численних епітетів, що є цілком природним, враховуючи те, що мета автора - іронічна характеристика. Іронія реалізується завдяки сполученням епітета з негативною конотацією з іменником, що має конотацію позитивну або нейтральну, і навпаки, а також використанню з іменником двох протилежних за значенням епітетів, наприклад: се cocon de douceur perverse ("Le caramel au beurre salé»); la gourmandise honteuse ("Le café gourmand»); la gourmandise torturée ("Le moelleux au chocolat»); ce dessert obscur ( Le moelleux au chocolat»); une énumération neurasthénique ( Le mot (petit»), une exhibition discrète ( (Les énumérations»), l’indication criante mais modeste ("Le ski»), fanfaronnade discrète ( (Les p’tits week-ends»).

Особливе місце посідає прикметник petit, - $\boldsymbol{e}$ (p’tit, - $\boldsymbol{e}$ - у розмовному мовленні), улюблений прикметник парижанина, завдяки якому, як іронічно відзначає О. Маньї, він применшує все, що пов'язане з утіхами, радощами життя, адже парижанину притаманна поміркованість (цій рисі присвячено навіть окремий розділ “Modération»): "A Paris, ce qui vient en abondance vient nécessairement en excès. Cette règle s'applique à tout. Et plus particulièrement aux choses les plus plaisantes de la vie: la nourriture, le soleil, le fun... Beaucoup de plaisir est à coup sûr trop de plaisir. Ainsi, pour tempérer les emportements de sa conscience, le Parisien fera généralement précéder toute référence à un plaisir de la vie par l'adjectif petit) ("Le mot (petit») [9, c. 195].

Petit дуже (зручний» прикметник, його використання позбавляє парижанина засоромлення від того, що він чомусь радіє, або щось робить йому втіху: “Le Parisien aime à guinder son plaisir: il rejoint ses amis dans "un p'tit restau», pour "une p’tite bière», "une p’tite blanquette de veau», "une p'tite soirée» ou "un p’tit week-end» («Le mot "petit») [9, с. 195-196]. Слід зазначити, що і сам автор дуже часто вживає цей прикметник, що цілком зрозуміло: він теж є парижанином. 
Неабияку роль у творенні іронічного ефекту в досліджуваному творі відіграють лексичні оказіоналізми (se new-yorkiser, coconverseur, guimauvisation, lookée, co-Berthilloneur, racaillisation). Так, Маньї використовує дієслово se new-yorkiser, говорячи, що Париж все більше стає схожим на Нью-Йорк: "Paris se new-yorkise chaque jour davantage. Le cool y supplante l'authentique, la valeur du nouveau dépasse celle de l'ancien, le museau vinaigrette fait place à la salade Caesar. Paris, doucement, se provincialise» («New York») [9, с. 128]. Іронічного негативно-оцінного смислу цей неологізм набуває завдяки контексту: (нью-йоркизація) виражається в тому, що Париж втрачає свою самобутність і потрохи перетворюється у провінцію (“se provincialise»).

Характеризуючи особливості мови парижан, О. Маньї вживає лексичний оказіоналізм verlaphone, щоб підкреслити звичність використання арго, яке вже не сприймається у Парижі як жаргон: "Certains mots de verlan sont aujourd'hui très communément usités par le Parisien de moins de quarante ans. Leur familiarité lui a fait perdre de vue leur nature verlanisée. $<\ldots>$ Les parures d'homme de la rue qu'ils lui permettaient d'arborer il y a quinze ans ont pris aujourd'hui de la patine. De populo, le Parisien est ainsi devenu verlaphone» («Le verlan») [9, c. 149].

Поряд з розглянутими вище лексико-стилістичними засобами ситуативна іронія виражається в досліджуваному творі за допомогою логіко-смислових прийомів, насамперед, використанням метафори. У більшості випадків метафори, що реалізують іронічну модальність, $\mathrm{\epsilon}$ оказіональними, оцінними та розгорнутими. Наведемо деякі приклади. "La chaussette blanche est le sommet du panthéon parisien du mauvais goût vestimentaire ("Les chaussettes blanches») [9, c. 60]. "... le bonbon au caramel au beurre salé demeure l'icône absolue, la caresse la plus experte» (“Le caramel au beurre salés) [9, c. 36]. "Avoir fait carrière, avoir une famille formidable ou être simplement quelqu'un de bien aideront, certes, mais n'effaceront jamais l'amertume contenue liée à ce virage raté, entre dix-huit et vingt ans) (Les grandes écoles») [9, с. 65]. (Тут йдеться про престижні заклади вищої освіти Grandes écoles).

Вживаною в досліджуваному творі є синестезія - тип метафори, що не тільки наділяє предмет формою та змістом, але й активізує почуття читача на фізичному рівні. Наприклад, у розділі «L'huile d'olive» знаходимо: "Le Parisien préfère à cette vision humide et rustre un monde plus onirique, nourri de soleil de Provence et du travail d'un "passionné». L'huile d'olive fait du bien au corps du Parisien, mais aussi à son esprit. Sur l'autel du glamour gastronomique ensoleillé, un seul condiment peut rivaliser avec elle: le vinaigre balsamique» [9, с. 169-170]. Синестезія посилює чуттєве сприйняття тексту, підкреслює його іронічну тональність.

Kрім того, в розділі “Le café gourmand» автор, наприклад, використовує метафору-персоніфікацію, коли стравам надаються людські якості та характеристики: "Plus récemment, le Parisien s'est mis à trouver dans le dessert le coupable idéal: trop cher, trop calorique, trop long... Pauvre dessert. Pendant ce temps-là, le café fanfaronnait - content de lui. Fréquemment accompagné d'un p'tit chocolat - moqueur et narquois, presque arrogant) [9, c. 52].

Суперечливість натури парижанина може передаватися за допомогою оксюморона, як наприклад: “Mais parfois, la promenade n'aura d'autre but qu'elle-même. Elle aura alors toujours le parfum doux-amer du temps qui passe. Doux-amer est un parfum cher au Parisien» ("L'Ile Saint-Louis») [9, c. 18]. Кисло-солодкий аромат є дорогим серцю парижанина, проте він може стати кислим-кислим, коли йдеться про неділю: “Les dimanches occidentaux ont tous la même saveur: ce doux-amer de fin de week-end. Le Parisien redoute ce jour plus que tout autre. Car à Paris, le dimanche est amer-amer..." ( (Le cinéma le dimanche») [9, c. 31].

Актуалізатором іронічної модальності в досліджуваному творі є також гіпербола. Наведемо їі яскраві приклади, які автор використовує в розділі “Les Américains», де парижани висловлюються найрізкішим та найкатегоричнішм чином щодо американців, зокрема, стосовно їх низького рівня культури та дурного характеру: "Les Américains sont tous gros et idiots. Point». "Les Américains, ils sont hyper superficiels» [9, c. 101]. Тут Маньї іронічно зауважуч: ані те, що Америка - найбагатша, найсильніша держава у світі, ані те, що парижани носять американський одяг, слухають американську музику, не впливає на таку оцінку. Найголовніше, американцям притаманні щиросердність, ентузіазм та оптимізм. В очах парижанина ці якості є симптомами однієї з форм інтелектуального переродження, свідчення відсутності витонченості. Це смертний гріх: "Ӓ Paris, ces traits de caractère sont les symptômes discrets d'une forme de dégénérescence intellectuelle, la preuve d'une absence aiguë de raffinement. Péché capital") [9, c. 101].

Іронія автора щодо нетерпимого та зухвалого ставлення парижан до мешканців Америки, підсилюється описом в розділі «New York» гарячої любові парижан до культури Нью-Йорку, нібито вона не має нічого спільного з американською та потрапила до цієї країни хіба що випадково: „Le Parisien ressentira alors le besoin irrépressible de proclamer au monde son amour pour New York". "Il est en effet impossible qu'un New-Yorkais soit autre chose que "super cool» [9, c. 127].

Асоціативна іронія виражається у книзі О. Маньї з використанням лексичного повтору. Як приклад наведемо стилістично маркований варваризм сооl (жарг. "крутий») і його варіант із префіксом інтенсивності super-cool, які вжито в дев'ятьох розділах (“Les sushis», "Parler anglais», "Les tomates cerises", "Le marché», "Le mot sympa", "New York", "Les gens "fun", "Les p'tits week-ends", "Les bobos») у 60-ти контекстах, з них у 14-ти він є іменником, у 16 - прикметником. 
У першому розділі, в якому вжито cool («Les sushis»), Маньї пояснює, що le Parisien cool («крутий парижанин») - це парижанин молодше сорока років, оскільки, як додає автор, кожен парижанин такої вікової категорії вважає себе крутим. Далі дізнаємось, крутість у Парижі визначається таким: мати iPhone, носити кеди Converse, їсти суші щонайменше двічі на тиждень, говорити англійською, замість звичайних томатів їсти томати чері, йти на ринок, одягшись якомога недбало, носити футболку з надписом I Love New York, час від часу від'їжджати з Парижа на вихідні. Іронічний ефект, що створюється невідповідністю значення слова (крутість) і банальністю ознак, якими вона визначається, посилюють коментарі автора, в яких він розкриває справжню сутність цих ознак. Наприклад, парижанин не купує звичайні томати (в моді томати чері), але ж залюбки їсть їх, коли потрапляє кудись у провінцію; до твердження про те, що парижанин добре володіє англійською, автор додає іронічно: «зазвичай, краще ніж французькою»; парижанин їде на вихідні кудись за межі Парижу не для того, як він стверджує, аби подихати свіжим повітрям, а для того, щоб мати про що розповідати друзям та колегам.

Читач, який сприймає інформацію, виражену у формі іронії, піддається більшій емоційній дії, оскільки зіштовхується з проблемою декодування іронічного контексту, що, у свою чергу, потребує від нього апелювання до його фонових знань, досвіду і т. д. [1, с. 10-11]. У випадку аналізованого твору ця теза підтверджується на прикладах іронічної алюзії, яку знаходимо в розділах “Porter du noir», "Le cinéma le dimanche», "Le café gourmand», "New York». Описуючи схильність парижанок дотримуватися моди на колір пори року, як у випадку блакитного: „Marcher dans les rues de Paris un été "bleu" donnera l'étonnante impression au promeneur de flâner dans un étrange village schtroumpf" («Porter du noi») [9, с. 22] автор проводить аналогію з вигаданими бельгійським художником П'єром Кюлліфором (Пейо) персонажами мультфільму “Смурфіки» — гномами зі шкірою блакитного кольору.

Алюзію на Троянського коня знаходимо в розділі "Le caramel au beurre salé»: "Le Parisien pourra trouver son caramel au beurre salé dans bon nombre de petits poneys de Troie: la glace, les macarons, les bonbons... De cette cavalerie joufflue, le bonbon au caramel au beurre salé demeure l'icône absolue, la caresse la plus experte» [9, с. 36]. Тут морозиво, макарони, цукерки, як і солона карамель, іронічно порівнюються з троянськими поні (очевидно, через їх невеликий розмір), оскільки вони ховають всередині цукор, такий ненависний парижанам.

У розділі „Le cinéma le dimanche» автор називає парижан, що у неділю біжать від сірої реальності до кінотеатрів в пошуках яскравих кольорів, "les boat people de la grisaille»: "Le Parisien sait que si la réalité est grise, une salle de cinéma est un bel endroit où retravailler la couleur pour quelques heures. $<\ldots>$ Paris compte le plus grand nombre de salles de cinéma au monde, toutes immanquablement prises d'assaut le dimanche par des hordes aspirant à la couleur. Les boat people de la grisaille. Avec pudeur, les Parisiens restent romantiques) [9, с. 32-33]. Це словосполучення відсилає читача до фактів із сучасної світової історії (boat people позначало в'єтнамських біженців, що рятувалися, тікаючи через море під час трьох Індокитайських війн).

Висновки. Весь текст книги (Dessine-moi un Parisien” є іронічно маркованим. Основною функцією, яку іронія виконує у творі О. Маньї, є фуннкція вираження авторської оцінки, іронічної портретизації сучасного парижанина. Засоби вираження ситуативної та асоціативної іронії створюють експресивно-оцінний тон книги, сприяючи реалізації авторської інтенції - розкрити суперечну натуру парижанина.

Ефективними актуалізаторами іронічного смислу у книзі О. Маньї є також синтактико-стилістичні засоби, дослідження яких видається перспективним у подальших розвідках.

\section{Jime ратура}

1. Ваулина С. С., Булатая Е. В. Средства выражения иронии в немецкоязычных переводах гоголевских текстов. Научный диалог. Москва, 2019. № 3. С. 9-23.

2. Горностаева А. Ирония как компонент английского стиля коммуникации. Москва : 000 "ИПЦ "МАСКА", 2013. $240 \mathrm{c}$.

3. Горностаева А. А. Ирония и комическое в английской и русской лингвокультуре. Мир лингвистики и коммуникаиии : электронный научный журнал. 2018. №2. С. 101-115. URL : http://tverlingua.ru/

4. Калита О. М. Засоби іронії в малій прозі (кінець XX - початок XXI століття). Киӥв : Вид-во НПУ імені М. П. Драгоманова, 2013. 238 с.

5. Коновалова О. А. Функциональная трансформация иронии в эпоху потмодерна. Исторические, философские, политические и юридические науки, культурология и искусствоведение. Вопросы теории и практики. Тамбов : Грамота, 2011. № 1 (7). С. $120-122$.

6. Пивоев В. М. Ирония как феномен культуры. 2-е изд., стер. Москва ; Берлин : Директ-Медиа, 2017. 113 с.

7. Походня С. И. Языковые виды и средства реализации иронии. Киев: Наукова думка, $1989.126 \mathrm{c.}$

8. Смирнова С. И. Особенности реализации иронии в описательном и повествовательном типах речи. Вестник Иркутского гос. лингвистического ун-та. 2012. Вып. 4 (25). С. 284-289.

9. Magny 0. Dessine-moi un Parisien. Paris : Éditions 10/18, 2010. 238 p.

10. Morosan N.-L. Les interférences linguistiques dans l'(auto)dérision du portrait d'un Parisien. URL : http://www. diacronia.ro/ro/indexing/details/A17762/pdf 
References

1. Vaulina, S. S., Bulataya, E. V. (2019), "Means of irony expression in german translations of Gogol's texts», Scientific dialogue ["Sredstva vyrazheniya ironii v nemeckoyazychnykh perevodakh gogolevskikh tekstov», Nauchnyy dialog], Moscow, vol. 3, pp. 9-23.

2. Gornostaeva, A. A. (2013), Irony as a component of english style communication [Ironiya kak komponent angliyskogo stilya kommunikatsii], Publishing house IPC «Maska», Moscow, 240 p.

3. Gornostaeva, A. A. (2018), "Irony and comic in English and Russian linguistic culture», The world of linguistics and communication : electronic scientific journal ["Ironiya i komicheskoe v angliyskoy i russkoy lingvokul'ture», Mir lingvistiki $i$ kommunikatsii : elektronnyy nauchnyy zhurnal], vol. 2 , pp. 101-115, available at : http://tverlingua.ru/

4. Kalyta, O. M. (2013), Means of irony in a small prose (the end of XX - the beginning of XXI century) [Zasoby ironii $v$ malii prozi (kinets' $X X-$ pochatok XXI stolittia)], National Pedagogical Dragomanov University Press, Kyiv, $238 \mathrm{p}$.

5. Konovalova, O. A. (2011), "Functional transformation of irony in the postmodern era", Historical, philosophical, political and judicial sciences, cultural studies and art history. Questions of theory and practice [ Funktsional'naya transformatsiya ironii v epokhu postmoderna", Istoricheskie, filosofskie, politicheskie I yuridicheskie nauki, kul'turologiya I iskusstvovedenie. Voprosy teorii i praktiki], Gramota, Tambov, vol. 1 (7), pp. 120-122.

6. Pivoev, V. M. (2019), Irony as a cultural phenomenon, $2^{\text {nd }}$ ed. [Ironiya kak fenomen kul'tury, 2-ye izd.], Direct-Media, Moscow, Berlin, 113 p.

7. Pohodnya, S. I. (1989), Language types and means of irony realization [Yazykovye vidy I sredstva realizatsii ironii], Naukova dumka, Kiev, $126 \mathrm{p}$.

8. Smirnova, S. I. (2012), "Peculiarities of irony realization in descriptive and narrative types of speech", Herald of the Irkutsk State Linguistic University ["Osobennosti realizatsii ironii v opisatel'nom i povestvovatel'nom tipakh rechi”, Vestnik Irkutskogo gos. lingvisticheskogo universiteta], Irkutsk, vol. 4 (25). pp. 284-289.

9. Magny 0. (2010), Dessine-moi un Parisien, Éditions 10/18, Paris, 238 p.

10. Morosan, N.-L. "Les interférences linguistiques dans l'(auto)dérision du portrait d'un Parisien», available at: http://www.diacronia.ro/ro/indexing/details/A17762/pdf

\section{МАРИНАШВИЛИ Мальвина Джангизовна,}

кандидат филологических наук, доцент, заведующая кафедрой французской филологии Одесского национального университета имени И. И. Мечникова; Французский бульвар, 24/26, г. Одесса, 65058, Украина; тел.: +38 098 4406757; e-mail: malvimari@gmail.com; ORCID ID: 0000-0002-3041-7064

\section{ЯЗЫКОВЫЕ СРЕДСТВА СОЗДАНИЯ ИРОНИЧЕСКОЙ МОДАЛЬНОСТИ В КНИГЕ ОЛИВЬЕ МАНЬИ "DESSINE-MOI UN PARISIEN"}

Аннотация. Цель статьи заключается в выявлении и анализе лингвостилических средств актуализации иронической модальности в книге Оливье Маньи (Dessine-moi un Parisien») (“Нарисуй мне парижанина»), которая относится к жанру нон-фикшн. Объектом исследования является вербально выраженная ироническая модальность. Предмет изучения - языковые средства, которые способствуют созданию иронических смыслов в книге Оливье Маньи. Peзультатом проведённого исследования явилось выявление и описание средств реализации авторской иронической модальности при создании образа современного парижанина как на уровне микроконтекста, так и на уровне целого текста. Описаны лексико-стилистические и логико-смысловые средства создания иронической модальности (эпитеты, лексические окказионализмы, метафора, гипербола, оксюморон), а также средства актуализации ассоциативной иронии (лексический повтор, аллюзия). Сделан вывод о том, что основной функцией, которую ирония выполняет в книге О. Маньи, является функция иронической (авто)портретизации, выражения авторской оценки. Ирония в исследованном произведении основана на раскрытии противоречивого характера парижанина, несоответствия между его внешним представлением, видимостью, и его истинной сущностью, какой её видит автор анализируемого произведения, сам коренной парижанин.

Ключевые слова: ироническая модальность, лингвостилистические средства, французский язык, нон-фрикшн, Оливье Маньи.

Malvina D. MARINASHVILI,

Candidate of Philological Sciences (PhD), Associate Professor, Head of the Chair of French Philology, Odessa

I. I. Mechnikov National University; 24/26, Frantsuzkyi blvd, Odessa, 65058, Ukraine; tel.: +38 0984406757 ; e-mail: malvimari@gmail.com; ORCID ID: 0000-0002-3041-7064

\section{LANGUAGE MEANS OF CREATING IRONIC MODALITY IN THE BOOK “DESSINE-MOI UN PARISIEN» BY OLIVIER MAGNY}

Summary. The purpose of the article is singling out and analyzing of language means expressing ironic modality in the non-fictional book "Dessine-moi un Parisien" ("Paint Me a Parisian») by Olivier Magny. The object of the study is verbally expressed ironic modality. The subject of the research is language means providing ironic connotation in O. Magny's book. The result of the investigation has allowed distinguishing and analyzing the author's ironic modality colouring of the image of a modern Parisian both on the level of the micro-context and the whole text. The lexical-stylistic and logical-semantic means of conveying ironic modality (epithets, lexical occasionalisms, metaphor, hyperbole and oxymoron), as well as the means of creating associative irony (lexical repetition, allusion) have been described. The main conclusion of the paper is that the chief function fulfilled by irony in the work by O. Magny is creating ironic (auto)portrait, as well as 
expressing the author's evaluation. The irony in the work under study is based on the unveiling a Parisian's contradictory nature, the discrepancy between visibility and his true essence seen through the author's eyes being a born and bred Parisian himself. Syntactic and stylistic tools are also effective actualizers of the ironic sense in O. Magny's book. Their study seems promising in further exploration.

Key words: ironical modality, linguostylistic means, french language, non-fiction, Olivier Magny.

Статтю отримано 27.09.2019 p.

http://dx.doi.org/10.18524/2307-4558.2019.32.187770

УДК [811.111+821.111]'276.3-055.2'282.4-32:159.923'06(73)

ПАЗИНА Светлана Валерьевна,

магистр 2 года обучения, филологический факультет Одесского национального университета имени

И. И. Мечникова; Французский бульвар, 24/26, г. Одесса, 65058, Украина; тел.: +38 (067) 5593199;

e-mail: puma.pp85@gmail.com; ORCID ID: 0000-0003-2649-5198

СТЕПАНОВ Евгений Николаевич,

доктор филологических наук, зав. кафедрой русского языка Одесского национального университета имени

И. И. Мечникова; Французский бульвар, 24/26, г. Одесса, 65058, Украина; тел.: +38 0487762277 ;

+38 096 4966406; e-mail: e.stepanov@onu.edu.ua; ORCID ID: 0000-0002-5441-9822

\section{ПОРТРЕТ АФРО-АМЕРИКАНКИ В РАССКАЗАХ СОВРЕМЕННЫХ АМЕРИКАНСКИХ ПИСАТЕЛЬНИЦ КАК ОСНОВА СОЗДАНИЯ ИНДИВИДУАЛЬНОЙ И КОЛЛЕКТИВНОЙ ИДЕНТИЧНОСТИ}

Аннотация. Цель статьи - изучить на основе литературного материала лингвостилистические особенности портретных описаний афро-американок в литературных произведениях; выявить основные закономерности и принципы, которые применяются при создании портретных описаний в анализируемых рассказах; выделить типические черты афро-американской коллективной (этнической, социальной, гендерной) идентичности. Объект анализа - портрет афро-американки как один из компонентов художественного текста и форма создания целостного образа литературного героя - чернокожей женщины в США - как центральной текстовой категории. Предмет исследования - лексические средства создания образа персонажа, актуализированные стилистические приёмы: эпитет, метафора, образное сравнение - в портретной характеристике афро-американки и частота и их использования в художественных текстах. Особое внимание уделяется графону как средству передачи речевого портрета персонажа. В результате проведённого исследования сделан ряд выводов. В частности, афро-американская женщина в США как представительница данной этнической группы является полноправным носителем афро-американского варианта английского языка. В проанализированных рассказах она, по обыкновению, предстаёт как необразованная женщина низкого социального статуса, что находит отражение в её речи в виде многочисленных графонов. Преобладающее количество лексических единиц, употреблённых в текстах при создании портретного образа, содержит эмоционально-оценочный компонент, реализуемый в тексте посредством использования прилагательных и наречий, чаще всего выступающих в качестве эпитетов. Практическое применение результатов исследования состоит в необходимости их использования при системном подходе к изучению структурной единицы художественного целого - портрета - с лингвистической точки зрения. Это позволит делать более полные заключения о характере системных связей в произведении.

Ключевые слова: портрет, портретные характеристики, афро-американка, идентичность, образ персонажа, стилистические приёмы, языковые средства.

Постановка проблемы. Научная парадигма XXI века характеризуется необычайным интересом $\kappa$ проблематике идентичности личности и группы. Внешность человека всегда привлекает к себе повышенное внимание и играет важную роль в жизни человека. Каждого интересует, как он выглядит, что в нём есть наиболее привлекательного. Для филолога портрет предстаёт в гораздо более широком значении, чем для нефилолога: это не только внешность, жесты, мимика, телодвижения, но и черты характера, речевой портрет, а также психологическое состояние человека. Портрет отличается определённой лингвостилистической организацией. Изучение портрета напрямую связано с проблемой феномена идентичности, который представляет безусловный интерес и для лингвистического анализа. На современном этапе в отечественной и зарубежной лингвистике изучается круг проблем, связанных с языковой репрезентацией идентичности. Хотя понятие идентичности признаётся базовым термином многих современных гуманитарных наук, оно всё ещё пребывает в стадии обсуждения, уточнения, корректировки.

Постановка задач исследования. В данной статье мы попытались показать, как элементы индивидуальных портретов складываются в собирательный портрет афро-американки, позволяющий выделить типические черты афрро-американской коллективной (этнической, социальной, гендерной) 